\title{
Physiological Traits and Ions Content of Olive as Affected by Bio-Organic Fertilizers under Saline Conditions
}

\author{
Syed Ishtiaq Hyder ${ }^{1}$, Muhammad Arshad Ullah ${ }^{1 *}$, Shariq Mahmood Alam² and Syeda Sana Aamir ${ }^{2}$ \\ ${ }^{1}$ Land Resources Research Institute, National Agricultural Research Centre, Islamabad, Pakistan \\ ${ }^{2}$ Horticultural Research Institute, National Agricultural Research Centre, Islamabad, Pakistan \\ *Corresponding Author: Muhammad Arshad Ullah, Land Resources Research Institute, National Agricultural Research Centre, \\ Islamabad, Pakistan.
}

Received: June 28, 2019; Published: July 16, 2019

D0I: 10.31080/ASAG.2019.03.0576

\begin{abstract}
Optimizing olive growth parameters and nutrient contents, reducing chemical fertilizer cost and productive utilization of saline soil is the high time demand of oil importing country like Pakistan. Bio-organic sources like vermicompost and humic acid furnish one of the most promising alternatives to costly chemical fertilizers. The objective of the study was to determine the effects of humic acid (HA) and vermicompost on physiological traits and ion content of olive under saline conditions. Therefore, a greenhouse experiment was conducted at National Agricultural Research Centre, Islamabad, to investigate the effects of bio-organic fertilizer vermicompost [having C:N=15:1 and 14 Plant Growth Promoting Rhizobacteria (PGPR)] and humic acid on physiological traits and nutrients content in three olive varieties (Nocellera, Frontoio and Carloea) under saline conditions during 2017-18. The data revealed that combined application of vermicompost and humic acid produced varied and significant $(\mathrm{P}<0.05)$ effect on the physiological traits (shoot length, shoot fresh weight, shoot dry weight, leaf area, and chlorophyll\%) and N, K, Na contents of olive. Completely randomized design was applied with three replications. Humic acid (HA) and Vermicompost (100 mg kg-1) were applied to respective polythene bags filled with saline soil. All interventions were carried out at the time of plantation of three months olive cuttings. Results of this study indicated that all three olive varieties significantly performed well physiologically with the application of bio-organic fertilizers and HA @ $20 \mathrm{mg} \mathrm{kg-1}$. Among all varieties, Carolea attained the maximum shoot length, shoot dry weight and chlorophyll content followed by Frontoio. Similar trend has been registered in shoot $\mathrm{N}$ and $\mathrm{K}$ concentration in shoot. All treatments receiving humic acid and vermicompost together performed significantly better. The $\mathrm{N}$ and $\mathrm{K}$ concentration in olive shoot translated the maximum values, however, $\mathrm{Na}$ shoot concentration declined significantly with combined application of HA and vermicompost. Based on findings of this study it can be suggested that $\mathrm{HA}$ and vermicompost significantly improve physiological traits of olive varieties and enhance $\mathrm{N}$, $\mathrm{K}$ content of olive shoot and reduce Na shoot content.
\end{abstract}

Keywords: Olive Varieties; Vermicompost; Humic Acid; Saline Soil; Physiological Traits N, K and Na

\section{Introduction}

Olive is considered as a moderately salt tolerant plant [1]. The mechanism is located within the roots and prevents salt translocation, rather than salt absorption. It is a small to medium sized tree that is a major crop in the Mediterranean Basin countries and has been grown in other regions having similar climate in the southern hemisphere. The olive tree productivity is generally low due to the poor soil fertility and low water holding capacity.

The low soil fertility has raised the concerns about the sustainability of agricultural production. Strategies for increasing agricultural productivity focused on efficient utilization of available nutrient and effectively on sustainable basis for maintaining soil health. For sustainable agriculture, integrated management of the nutrients is needed for proper plant growth. Owing to the ever increasing cost of inorganic chemical fertilizers, the integration of inorganic fertilizers with organic manures and crop residues has become imperative for sustained crop production and maintenance of soil health [2]. Humic acid (HA) is an organically charged bio-stimulant that significantly affects plant growth and development and increases crop yield. HA improves physical, chemical and biological properties of soils [3-5]. The role of HA is well known in improving soil health and nutrient uptake by plants, mineral availability, fruit quality, etc [6]. Humic acid based fertilizers increase crop yield [7], enzymes/hormones and improve soil fertility in an ecologically and environmentally benign manner $[8,9]$. Humus originated from vermicompost is a finely divided manure peat like material with high porosity, aeration, drainage and water holding capacity and microbial activity and use of vermicompost in horticulture at large scale can solve the management and disposal problem associated with macrophytes and also resolves the deficiency of organic matter in such soils in addition to nutrient depletion. The 
presence of PGPR strains in vermicompost play an important role in in-creasing availability of nitrogen and phosphorus besides improving biological fixation of atmospheric nitrogen and enhancing phosphorus availability to crop and growth promoting substances like enzymes and hormones, along with plant nutrients make them essential for improvement of soil fertility and productivity [10].

Declining soil fertility due to salinity, ever increasing fertilizer costs and continuous increasing oil consumption demand, it is imperative to adopt bio-organic fertilizers to reduce chemical fertilizer cost and environmental pollution. It has drowned the attention of olive growers to use the organic and bio-organic fertilizers that would be healthy for human and safe for environment [11]. Keeping in view these facts, the study was planned with the objective to investigate the effect of $\mathrm{HA}$ and vermicompost on improvement in physiological traits and $\mathrm{N}, \mathrm{K}$ content of olive cuttings under saline soil condition.

\section{Materials and Methods}

This study was carried out to see the physiological traits like shoot length, shoot fresh weight, shoot dry weight, leaf area, chlorophyll content and ions content as affected by bio-organic fertilizers including humic acid (HA) and vermicompost of three olive varieties i.e., Nocellera, Frontoio and Carloea under naturally saltaffected soil (ECe $=5.37 \mathrm{dS} \mathrm{m}^{-1} ; \mathrm{pH}=8.58$ ) during 2017-18 at National Agricultural Research Centre, Islamabad. The latitude and longitude of Islamabad is $33^{\circ} 42^{\prime} \mathrm{N}, 73^{\circ} 10 \mathrm{E}^{\prime}$. The plastic bags were filled with naturally saline sandy clay loam soil having physicochemical properties as mentioned in table 1 . Three months olive sprouted cuttings varieties were transplanted in plastic nursery bags following Completely Randomized Design (Factorial) with three replications. Humic acid and vermicompost were applied in respective polythene bags at the time of plantation. Treatments were as follows:

$$
\begin{aligned}
& \mathrm{T} 1=\text { Control (No HA) } \\
& \mathrm{T} 2=\mathrm{HA} 10 \mathrm{mg} \mathrm{Kg}^{-1} \text {, } \\
& \mathrm{T} 3=\mathrm{HA} 15 \mathrm{mg} \mathrm{kg}^{-1} \\
& \mathrm{~T} 4=\mathrm{HA} 20 \mathrm{mg} \mathrm{kg}^{-1}
\end{aligned}
$$

\begin{tabular}{|l|c|c|}
\hline Parameters & Unit & Values \\
\hline $\mathrm{pH}$ & - & 8.58 \\
\hline $\mathrm{ECe}(1: 1)$ & $\mathrm{dS} \mathrm{m}^{-1}$ & 5.37 \\
\hline $\mathrm{CaCO}_{3}$ & $\%$ & 2.59 \\
\hline $\mathrm{OM}$ & $\%$ & 0.34 \\
\hline $\mathrm{NO}_{3}-\mathrm{N}$ & $\mathrm{mg} \mathrm{kg}^{-1}$ & 2.12 \\
\hline Extractable P (AB-DTPA) & $\mathrm{mg} \mathrm{kg}^{-1}$ & 2.68 \\
\hline Extractable K (AB-DTPA) & $\mathrm{mg} \mathrm{kg}^{-1}$ & 79.81 \\
\hline Sand & $\%$ & 31.72 \\
\hline Silt & $\%$ & 28.27 \\
\hline Clay & $\%$ & 40.11 \\
\hline Textural Class & - & Sandy clay loam \\
\hline
\end{tabular}

Table 1: Physico-chemical analysis of the soils.
The treatments were with and without Vermicompost. Humic acid was mixed into soil at the time of planting whereby vermicompost was also mixed @ $100 \mathrm{mg} \mathrm{kg}^{-1}$ at the time of planting olive cuttings. The soil sample collected for physic-chemical analysis was carried out following the method described by Ryan., et al. [12]. Olive plant samples were collected after three months of cutting establishment. Olive plant data on shoot length, shoot fresh weight, shoot dry weight, leaf area and chlorophyll content. Plant samples collected for $\mathrm{N}, \mathrm{K}$ and $\mathrm{Na}$ concentration in plant tissues were dried in oven at $60^{\circ} \mathrm{C}$ till constant weight. Ground plant samples were digested in perchloric-nitric acid $(2: 11 \mathrm{~N})$ mixture [13] and $\mathrm{Na}$, and $\mathrm{K}$ were estimated using atomic absorption spectrophotometer. For $\mathrm{N}$ determination, plant samples were digested with sulphuric acid, using auto-analyzer. Total $\mathrm{N}$ was measured through sulphuric acid digestion. For distillation Micro-Kjeldahl method [14] was used. Vermicompost sample was analyzed for physico-chemical properties (Table 2) using standard methods described by ICARDA manual [12]. The data thus obtained were subjected to statistical analysis according to Gomez and Gomez [15].

\section{Results and Discussion}

Vermicompost and HA application significantly affected plant growth parameters. Results in table 3 regarding olive shoot length, shoot fresh weight and shoot dry weight showed that Frontoio, olive variety attained the highest shoot length $(8.6 \mathrm{~cm})$ with the combined application of vermicompost and HA application @ $20 \mathrm{mg}$ kg-1 closely followed by Carloea (7.6 cm shoot length) under the same treatment. Similar trend were recorded in shoot fresh weight and shoot dry weight. Nocellera and Frontier, registered the maximum shoot fresh weight $(9.2 \mathrm{~g})$ followed by Carloea shoot fresh weight (8.46g). However, Carloea recorded the maximum shoot dry weight (5.1g) followed by Nocellera and Frontoio (4.1g) with combined application of vermicompost and HA @ $20 \mathrm{mg} \mathrm{kg}^{-1}$. These observations are in accordance with those obtained by Fathy., et al. [16] who stated that physical and chemical properties of 'Canino' apricot fruit was progressively increased as foliar and soil doses of HA increased. Similar findings in tomato crop were also reported by Bath., et al [10]. Comparatively higher plant growth under HA and vermicompost treatment might be due to more readily available nutrients and plant growth regulating substances of PGPR present in vermicompost having beneficial hormones (like Indole Acetic Acid (IAA), Gibberellins, Cytokinines) that promoted greater root initiation causing more nutrient availability which increased root biomass and enhanced plant growth. This could be supported by the findings of Pritam., et al. [17]. Similarly, Magdi., et al. [18] reported that bio-fertigation of microbial inoculums and HA substances could be used as a complementary for mineral fertilizers to improve yield and quality of cowpea. Vermicompost as foliar sprays, also promoted the growth of tomato plants [19], and strawberries [20]. 


\begin{tabular}{|l|c|c|}
\hline \multicolumn{1}{|c|}{ Parameters } & Unit & Values \\
\hline $\mathrm{pH}$ & - & 7.63 \\
\hline $\mathrm{ECe}(1: 1)$ & $\mathrm{dS} \mathrm{m}^{-1}$ & 3.00 \\
\hline Total N & $\%$ & 2.30 \\
\hline Total P & $\%$ & 0.31 \\
\hline $\mathrm{K}$ & $\%$ & 2.00 \\
\hline OM & $\%$ & 25.00 \\
\hline C:N & & $15: 1$ \\
\hline PGPR Strains & & 14.00 \\
\hline
\end{tabular}

Olive leaf area and chlorophyll content were also significantly improved by combined application of HA and vermicompost. Data in table 4 indicate that Carloea recorded the maximum leaf area $\left(26 \mathrm{~cm}^{2}\right)$ with the combined application of HA and vermicompost @ $20 \mathrm{mg} \mathrm{kg}^{-1}$ followed by Nocellera having leaf area $\left(25.33 \mathrm{~cm}^{2}\right)$ under the same treatment. Olive varieties Carloea and Frontoio showed the maximum chlorophyll content (52.83\%) as compared to Nocellera $(50.13 \%)$ by the combined application of HA $(20 \mathrm{mg}$ $\mathrm{kg}-1$ ) and vermicompost. It may probably be owing to more nutrient availability unleashed HA substances as reported by Magdi., et al. [18] and plant growth regulating substances (PGPR) present in

Table 2: Physico-chemical analysis of the vermicompost.

Shoot Length $(\mathrm{cm})$

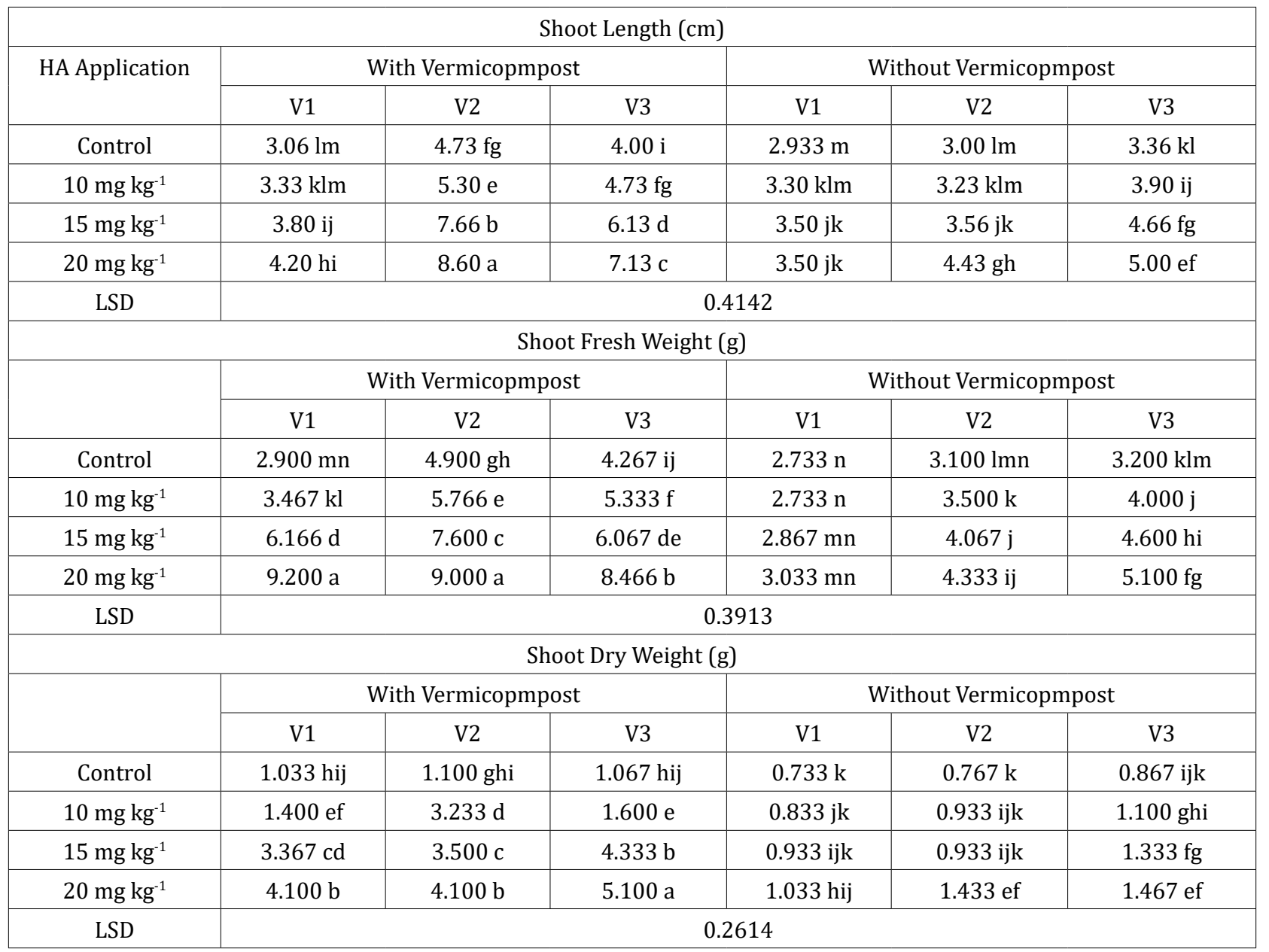

Table 3: Physiological traits of olive as influenced by combined application of humic acid, biozote with and without vermicompost under saline conditions (Average of three repeats). Means with different letters are significantly different at 5\% level of probability.

vermicompost releasing auxins as reported by Bath., et al. [10] that improved photosynthesis.

Nitrogen and $\mathrm{K}$ content in olive were significantly increased and Na content decreased significantly by application of HA and vermicompost. Data regarding olive shoot $\mathrm{N}, \mathrm{K}$ and $\mathrm{Na}$ content (Table 5) indicated that maximum N (3.06\%), K (3.23\%) and least $\mathrm{Na}(0.43 \%)$ content were recorded in plant tissues of all varieties through the combined application of HA $\left(20 \mathrm{mg} \mathrm{kg}^{-1}\right)$ and vermi- compost under saline conditions. These results were in consonance of the findings of Laila., et al. [21] whom reported that HA is especially beneficial in releasing nutrients in the rhizosphere so that they become available to the plant as per requirement. Humin substances influence plant growth both directly and indirectly by functioning as a major source of organic compounds in soil [22]. Humic Acid has protective effects against high saline stress by inhibiting $\mathrm{Na}+$ uptake in barley [23], and it reduced yield losses in maize under salt stress [24]. 


\begin{tabular}{|c|c|c|c|c|c|c|}
\hline \multicolumn{7}{|c|}{ Leaf Area $\left(\mathrm{cm}^{2}\right)$} \\
\hline \multirow[t]{2}{*}{ HA Application } & \multicolumn{3}{|c|}{ With Vermicopmpost } & \multicolumn{3}{|c|}{ Without Vermicopmpost } \\
\hline & V1 & $\mathrm{V} 2$ & V3 & V1 & V2 & V3 \\
\hline Control & 17.00 ghijkl & 16.33 hijkl & 17.00 ghijkl & $14.33 \mathrm{kl}$ & $13.66 l$ & 17.33 fghijk \\
\hline $10 \mathrm{mg} \mathrm{kg}^{-1}$ & 20.00 defg & $20.67 \mathrm{cdef}$ & 20.67 cdef & $15.33 \mathrm{jkl}$ & $15.33 \mathrm{jkl}$ & $15.67 \mathrm{ijkl}$ \\
\hline $15 \mathrm{mg} \mathrm{kg}^{-1}$ & $23.00 \mathrm{abcd}$ & 21.67 cde & $23.67 \mathrm{abc}$ & 17.00 ghijkl & 18.00 fghijk & 17.00 ghijkl \\
\hline $20 \mathrm{mg} \mathrm{kg}^{-1}$ & $25.33 \mathrm{ab}$ & 22.33 bcde & $26.00 \mathrm{a}$ & 19.00 efghi & 19.00 efghi & $19.33 \mathrm{efgh}$ \\
\hline LSD & \multicolumn{6}{|c|}{3.6133} \\
\hline \multicolumn{7}{|c|}{ Chlorophyll Content (\%) } \\
\hline & \multicolumn{3}{|c|}{ With Vermicopmpost } & \multicolumn{3}{|c|}{ Without Vermicopmpost } \\
\hline & V1 & V2 & V3 & V1 & V2 & V3 \\
\hline Control & $41.17 \mathrm{e}$ & $41.50 \mathrm{e}$ & $41.00 \mathrm{e}$ & $40.00 \mathrm{ij}$ & 40.67 hij & $39.67 \mathrm{j}$ \\
\hline $10 \mathrm{mg} \mathrm{kg}^{-1}$ & $45.50 \mathrm{~d}$ & $45.00 \mathrm{~d}$ & $46.167 \mathrm{~d}$ & 42.00 ghij & $41.33 \mathrm{hij}$ & 41.33 hij \\
\hline $15 \mathrm{mg} \mathrm{kg}^{-1}$ & $48.00 \mathrm{c}$ & $49.00 \mathrm{bc}$ & $49.33 \mathrm{bc}$ & $44.00 \mathrm{efg}$ & $43.00 \mathrm{fgh}$ & $43.00 \mathrm{fgh}$ \\
\hline $20 \mathrm{mg} \mathrm{kg}^{-1}$ & $50.17 \mathrm{~b}$ & $52.00 \mathrm{a}$ & $52.83 \mathrm{a}$ & $45.67 \mathrm{e}$ & $45.33 \mathrm{ef}$ & $45.67 \mathrm{e}$ \\
\hline LSD & \multicolumn{6}{|c|}{2.5225} \\
\hline
\end{tabular}

Table 4: Leaf area and Chlorophyll Content as influenced by application of humic acid and Biozote with and without vermicompost under saline conditions (Average of three repeats).

\begin{tabular}{|c|c|c|c|c|c|c|}
\hline \multicolumn{7}{|c|}{$\mathrm{N}(\%)$} \\
\hline \multirow[t]{2}{*}{ HA Application } & \multicolumn{3}{|c|}{ With Vermicopmpost } & \multicolumn{3}{|c|}{ Without Vermicopmpost } \\
\hline & V1 & V2 & V3 & V1 & V2 & V3 \\
\hline Control & $1.76 \mathrm{fgh}$ & $1.83 \mathrm{f}$ & $1.80 \mathrm{fg}$ & $1.63 \mathrm{hi}$ & 1.66 ghi & $1.53 \mathrm{i}$ \\
\hline $10 \mathrm{mg} \mathrm{kg}^{-1}$ & $2.03 \mathrm{e}$ & $2.13 \mathrm{de}$ & $2.06 \mathrm{e}$ & $2.00 \mathrm{e}$ & $2.06 \mathrm{e}$ & $2.03 \mathrm{e}$ \\
\hline $15 \mathrm{mg} \mathrm{kg}^{-1}$ & $2.36 \mathrm{bc}$ & $2.4 \mathrm{~b}$ & $2.4 \mathrm{~b}$ & $2.23 \mathrm{~cd}$ & $2.26 \mathrm{bcd}$ & $2.26 \mathrm{bcd}$ \\
\hline $20 \mathrm{mg} \mathrm{kg}^{-1}$ & $2.90 \mathrm{a}$ & $3.06 \mathrm{a}$ & $3.00 \mathrm{a}$ & $2.30 \mathrm{bc}$ & $2.36 \mathrm{bc}$ & $2.30 \mathrm{bc}$ \\
\hline LSD & \multicolumn{6}{|c|}{0.082} \\
\hline \multicolumn{7}{|c|}{$\mathrm{Na}(\%)$} \\
\hline & \multicolumn{3}{|c|}{ With Vermicopmpost } & \multicolumn{3}{|c|}{ Without Vermicopmpost } \\
\hline & V1 & V2 & V3 & V1 & V2 & V3 \\
\hline Control & 0.76 cde & $0.83 \mathrm{c}$ & $0.8 \mathrm{~cd}$ & $1.0 \mathrm{~b}$ & $1.10 \mathrm{a}$ & $1.06 \mathrm{ab}$ \\
\hline $10 \mathrm{mg} \mathrm{kg}^{-1}$ & $0.53 \mathrm{~g}$ & $0.5 \mathrm{gh}$ & $0.5 \mathrm{gh}$ & $0.8 \mathrm{~cd}$ & $0.83 \mathrm{c}$ & $0.83 c$ \\
\hline $15 \mathrm{mg} \mathrm{kg}^{-1}$ & $0.43 \mathrm{hi}$ & $0.43 \mathrm{hi}$ & $0.43 \mathrm{hi}$ & $0.66 \mathrm{f}$ & $0.73 \mathrm{def}$ & $0.70 \mathrm{ef}$ \\
\hline $20 \mathrm{mg} \mathrm{kg}^{-1}$ & $0.4 \mathrm{i}$ & $0.36 \mathrm{i}$ & $0.4 \mathrm{i}$ & $0.53 \mathrm{~g}$ & $0.53 \mathrm{~g}$ & $0.56 \mathrm{~g}$ \\
\hline LSD & \multicolumn{6}{|c|}{0.048} \\
\hline \multicolumn{7}{|c|}{$\mathrm{K}(\%)$} \\
\hline & \multicolumn{3}{|c|}{ With Vermicopmpost } & \multicolumn{3}{|c|}{ Without Vermicopmpost } \\
\hline & V1 & V2 & V3 & V1 & V2 & V3 \\
\hline Control & $1.90 \mathrm{~g}$ & $1.90 \mathrm{~g}$ & $2.13 \mathrm{f}$ & $1.70 \mathrm{~h}$ & $1.74 \mathrm{~h}$ & $1.70 \mathrm{~h}$ \\
\hline $10 \mathrm{mg} \mathrm{kg}^{-1}$ & $2.36 \mathrm{e}$ & $2.90 \mathrm{~b}$ & $1.96 \mathrm{~g}$ & $2.10 \mathrm{f}$ & $2.13 \mathrm{f}$ & $2.40 \mathrm{e}$ \\
\hline $15 \mathrm{mg} \mathrm{kg}^{-1}$ & $2.83 \mathrm{bc}$ & $2.36 \mathrm{e}$ & $2.83 \mathrm{bc}$ & $2.40 \mathrm{e}$ & $2.36 \mathrm{e}$ & $2.40 \mathrm{e}$ \\
\hline $20 \mathrm{mg} \mathrm{kg}^{-1}$ & $3.23 \mathrm{a}$ & $3.23 \mathrm{a}$ & $3.23 \mathrm{a}$ & $2.80 \mathrm{c}$ & $2.80 \mathrm{bc}$ & $2.66 \mathrm{~d}$ \\
\hline LSD & \multicolumn{6}{|c|}{0.044} \\
\hline
\end{tabular}

Table 5: Nitrogen, Na and K concentration (\%) in olive plant tissue as influenced by application of humic acid and Biozote with and without vermicompost under saline conditions (Average of three repeats).

Means with different letters are significantly different at $5 \%$ level of probability. 


\section{Conclusion}

This study concludes that all Olive varieties receiving HA and vermicompost together performed significantly better to physiological traits like shoot length, shoot fresh weight, chlorophyll content, leaf area and $\mathrm{N}, \mathrm{K}$ content in plant tissue translated the maximum values. However, $\mathrm{Na}+$ content in shoot declined significantly through combined application of HA and vermicompost. Based on the findings of this study, it could be concluded that combined use of HA and vermicompost have tremendous potential for sustainable olive growth. Whilst HA and vermicompost together increased physiological traits, $\mathrm{N}$ and $\mathrm{K}$ contents of olive however more detailed investigations are recommended to fully elucidate the role of HA and vermicompost on olive yield under field conditions.

\section{Bibliography}

1. Rugini E and E Fedeli. "Olive as an oilseed crop". In: Biotechnology in Agriculture and Forestry. Legumes and Oilseed crops Y. P. S. Bajaj (ed.) 10 (1990): 593-641.

2. Babulkar PS., et al. "Residual effect of long term application of FYM and fertilizers on soil properties and yield of soybean". The Indian Society of Soil Science 48.1 (2000): 89-92.

3. Keeling AA., et al. Crop and Environment Research Centre, Harper Adams University College, Newport, Shropshire, UK, Bioresource Technology 90 (2003): 127-137.

4. Nardi S., et al. "Rhizosphere: A communication between plant and soil". Recent Research Development in Crop Science 1 (2004): 349-360.

5. Mikkelsen RL. "Humic materials for agriculture, Davis, California, USA". Better Crops with Plant Food 89 (2005): 6-7.

6. Mauromicale G., et al. "The effect of organic supplementation of solarized soil on the quality of tomato". Scientia Horticulture 129 (2011): 189-196.

7. Mohamed A., et al. "Importance of micronutrients, organic manure and bio-fertilizer for improving maize yield and its components grown in desert sandy soil". Research Journal of Agriculture and Biological Sciences 5 (2009): 16-23.

8. Mart I. "Fertilizers, organic fertilizers, plant and agricultural fertilizers". Agro and Food Business Newsletter (2007): 1-4.

9. Sarir MS., et al. "Influence of different levels of humic acid application by various methods on the yield and yield components of maize". Sarhad Journal of Agriculture 21 (2005): 7581.

10. Bath TA., et al. "Yield, Soil Health and Nutrient Utilization of Field Pea (Pisum sativum L.) as Affected by Phosphorus and Biofertilizers under Subtropical Conditions of Jammu". International Journal of Modern Plant and Animal Science 1 (2013): 1-8.

11. Fayed TA. "Optimizing yield, fruit quality and nutration status of Roghiani olives grown in Libia using som organic extracts". Journal of Horticultural Science and Ornamental Plants 2 (2010): 63-78.
12. Ryan J., et al. "Soil and Plant Analysis Laboratory Manual". International Center for Agricultural Research in the Dry Areas (ICARDA), Aleppo, Syria (2001): 172.

13. Rhoades JD. Cation exchange capacity. In: Methods of Soil Analysis, Part 2: Chemical and Microbiological Properties, A. L. Pages, R.H. Miller and D.R. Keeney (eds.), 2nd edtion, pp. 149-158, American Society of Agronomy, Madison, Wisconsin, USA (1982).

14. AOAC. Association of Official Analytical Chemist. Official Methods of Analysis, 15th edition. Helrich, K. (ed). Arlington, Virginia, Washington, DC., USA (1994).

15. Gomez KA and Gomez AA. "Statistical Procedures for Agriculture Research". 2nd edition, John Wiley and Sons Inc., New York, USA (1984).

16. Fathy MA., et al. "Effect of Humic Acid Treatments on 'Canino' Apricot Growth, Yield and Fruit Quality". New York Science Journal 3 (2010): 109-115.

17. Pritam S., et al. "Growth and Yield Response of Marigold to Potting Media Containing Vermicompost Produced from Different Wastes". Environmentalist 30 (2010): 123-130.

18. Magdi TA., et al. "Integrated effects of bio and mineral fertilizers and humic substances on growth yield and nutrient contents of fertigated cowpea (vigna unguiculata L.)". Journal of agronomy 10 (2011): 34-39.

19. Tejada M., et al. "Agricultural use of leachates obtained from two different vermicomposting processes". Bioresource Technology 99 (2008): 6228-6232.

20. Singh R., et al. "Sequential foliar application of vermicompost leachates improves marketable fruit yield and quality of strawberry (Fragaria x ananassa Duch.)". Scientia Horticulturae 124 (2010): 34-39.

21. Laila F Hagagg., et al. "Optimizing fruit quality and quantity of "Aggizi" olive trees cultured in North Sinai by using some organic extracts". Middle East Journal of Applied Sciences 3 (2013): 17-23

22. Sangeetha M., et al. "Effect of lignite humic acid and fertilizers on the yield of onion and nutrient availability". Proc. 18th World Cong. Soil Sci. (2006): 9-15; Philadelphia, Pennsylvania, USA.

23. Marketa J., et al. "Humic acid protects barley against salinity". Acta Physiologiae Plantarum 38 (2016): 161.

24. Masciandaro G., et al. "Humic substances to reduce salt effect on plant germination and growth". Communications in Soil Science and Plant Analysis 33 (2002): 365-378.

\section{Volume 3 Issue 8 August 2019}

(C) All rights are reserved by Muhammad Arshad Ullah., et al. 